\title{
Naravni potenciali regij in njihova raba
}

\author{
Ana Vovk Korže \\ Dr., Oddelek za geografijo, Pedagoška fakulteta Maribor, \\ Koroška c. 160, 2000 Maribor, Slovenija \\ e-mail: ana.vovk@uni-mb.si
}

\section{Izvleček}

Zaradi neustrezne rabe naravnih potencialov se kažejo negativni vplivi v naravi, $v$ naravnih virih in v človekovem bivalnem okolju. Spreminjanje naravnih potencialov zaradi vpliva različnih dejavnosti načrtujejo študije ranljivosti okolja. Geografski vidiki so v teh študijah premalo zastopani, saj se uveljavljajo ozki sektorski interesi, ki zapostavljajo pomembnost okolja kot geografskega kompleksa. Na primeru Dravinjskih goric, ki je kontaktna regija med panonsko in alpsko Slovenijo, je prikazana raba naravnih potencialov na osnovi biotopov.

Ključne besede: biotopi, naravni potencial, raba tal, regija, trajnostni razvoj, Dravinjske gorice

\section{The Natural Potentials of Regions and their Use}

\begin{abstract}
Negative impact of activities on nature, natural resources and human environment occur because of natural resources misuse. Studies of vulnerability plan to modify natural resources because of influence of different activities. Geographical aspects in those studies are not presented well enoagh because of narrow sector interests, that diminish the importance of environment. Use of natural potential is presented on ground of biotope with the case study of contact region Dravinjske gorice, between Pannonian and alpine region.
\end{abstract}

Key words: biotop, natural potential, land use, region, sustainable development, Dravinjske gorice 


\section{UVOD}

Problematika naravnih potencialov in njihove rabe je aktualna od sedemdesetih let naprej, ko so strokovnjaki začeli opozarjati na meje rasti, povezane s končnostjo neobnovljivih virov, omejeno zmožnostjo obnavljanja obnovljivih virov in omejeno sposobnostjo okoljskih sestavin za sprejem in razgradnjo najrazličnejših snovi (omejeno samočistilno sposobnostjo). Že Ilešič (1974) je zapisal, da je ena izmed nalog geografije tudi preučevati naravne vire in gospodarjenje $\mathrm{z}$ njimi.

Za naravne vire se uporabljajo različni izrazi kot npr. naravni potenciali, naravni resursi, geopotenciali, pokrajinski viri in naravno bogastvo. Pomen besede naravni vir je širok. $V$ tehničnem smislu postane naravna danost bogastvo, ko ga začne izkoriščati človek. V šolski enciklopediji Geografija (1993) je naravni vir tisto, kar je v naravi koristnega za ljudi, to pa je lahko skoraj vse: npr. veter, voda, kamnine, prsti, surovine in celo pokrajina sama. V Enciklopediji Slovenije (št. 7, geslo naravni vir) je le ta definiran kot obnovljiva ali neobnovljiva naravna prvina, ki je gospodarsko uporabljiva. Nekateri obnovljivi naravni viri nastajajo sproti (les, ribe, divjad), na druge izkoriščanje bistveno ne vpliva (hidroenergija, sončna energija). V širšem smislu so naravni viri vse sestavine in značilnosti okolja, ki omogočajo obstoj življenja na Zemlji (zrak, voda, prst) oz. lahko zadovoljujejo posamezne potrebe ljudi, npr. proizvodne (rude, energetski viri, obdelovalna zemlja) ali rekreacijske (rekreacijska območja). Po definiciji Diercke Wörterbuch Allgemeine Geographie (1997 str. 451) je pokrajinski potencial »pozitivno učinkujoča danost pokrajine, posebno pomembna za ljudi in druga živa bitja.

Plut (1998, str. 32) uvršča med naravne potenciale biološki, samočistilni, hidrološki, atmosferski in potencial mineralnih surovin, torej materialne in nematerialne potenciale. $\mathrm{V}$ literaturi so naravni potenciali tiste komponente pokrajine, ki lahko imajo posredno ali neposredno ekonomsko ali naravovarstveno funkcijo, klimatsko funkcijo, doživljajsko in sprostitveno vrednost ali so biotsko pomembne. V študijah ranljivosti okolja (ŠRO MO Nova gorica, 2000) so naravni potenciali definirani ožje in zajemajo le materialne potenciale (vode, zrak, gozd, prst ipd). Nematerialnih potencialov kot so samočistilni, doživljajski in drugih študije ranljivosti okolja ne vključujejo.

Pri načrtovanju rabe naravnih potencialov je potrebno obravnavati različne potrebe in interese razvoja $\mathrm{v}$ prostoru glede na razpoložljive potenciale ter zagotoviti usklajenost gospodarskih, družbenih in okoljskih vidikov. $\mathrm{Z}$ rabo naravnih virov se spreminjajo: 


\section{fizično okolje}

(torej naravno okolje in njegove sestavine kot so površje, vode, zrak, prsti, vegetacija)

\section{antropogene sestavine okolja}

(vključujejo poselitvene sisteme, kvaliteto življenja, vplive na počutje ljudi, ki ga sooblikuje njihovo zdravstveno stanje, vizualni izgled bivalnega okolja, fiziognomija poselitve, gospodarjenje z odpadki, hrup, čistost okolja, dostop do zelenih površin)

\section{ekonomski vidik okolja}

stroški, ki se pojavljajo v okolju zaradi negativnih vplivov gospodarskih ali negospodarskih dejavnosti. Poznavanje stroškov v regiji zaradi posledic ekološko neustreznih dejavnosti je pomembno, saj višji stroški zmanjšujejo konkurenčnost gospodarstva.

Cilj prispevka je:

- opredeliti naravne potenciale in njihovo rabo;

- prikazati zveze med rabo naravnih potencialov in trajnostnim razvojem na osnovi strateških dokumentov;

- prikazati naravne potenciale in njihovo rabo na podlagi biotopske členitve regije Dravinjske gorice in ter rezultate primerjati z dosedanjimi.

\section{TEORETIČNO- METODOLOŠKI DEL}

Poznavanje stanja okolja in naravnih virov je ena od temeljnih informacij o regiji. Te informacije, skupaj s socialno-ekonomskimi značilnostmi, so podlaga za določanje prioritet trajnostnega razvoja. Pri načrtovanju dejavnosti v prostoru se upoštevajo naslednji koraki, povezani z naravnimi viri (Strateške presoje vplivov regionalnih razvojnih programov na okolje 2000):

$>$ Ugotoviti značilnosti naravnih virov: izhodiščne informacije o okolju se običajno nanašajo na kakovost zraka, kakovost in dostopnost vode, naravne vire, zavarovana območja itd. Še zlasti je pomembno poznati njihovo nosilno zmogljivost.

$>$ Opisati značilnosti naravnih virov: razpoložljivost naravnih virov (npr. dobri potenciali za izkoriščanje obnovljive energije, veliko naravnih območij, 
ali omejeni viri pitne vode, omejena zmogljivost čiščenja odpadnih voda in ravnanje s trdimi odpadki. Opisi so pogosto kvantificirani v obliki statističnih kazalcev in podatkov).

$>$ Ugotoviti značilnosti pritiskov na naravne vire. Pritiski na okolje se pojavljajo v sektorjih kot so promet, kmetijstvo, industrija, energetika v smislu njihovega vpliva na stanje okolja (poraba naravnih virov in vplivi na kakovost okolja v smislu onesnaževanja).

V dosedanjih geografskih študijah o ranljivosti okolja (Študija ranljivosti okolja, 1996) so avtorji izhajali iz okolja in njegove ranljivosti. V novejših študijah ranljivosti okolja, v katerih niso sodelovali geografi, je izhodišče za ugotavljanje ranljivosti okolja dejavnost in njen vpliv na okolje, kar pa ne vključuje kompleksnosti okoljskih povezav.

Shema 1: Vrste naravnih virov

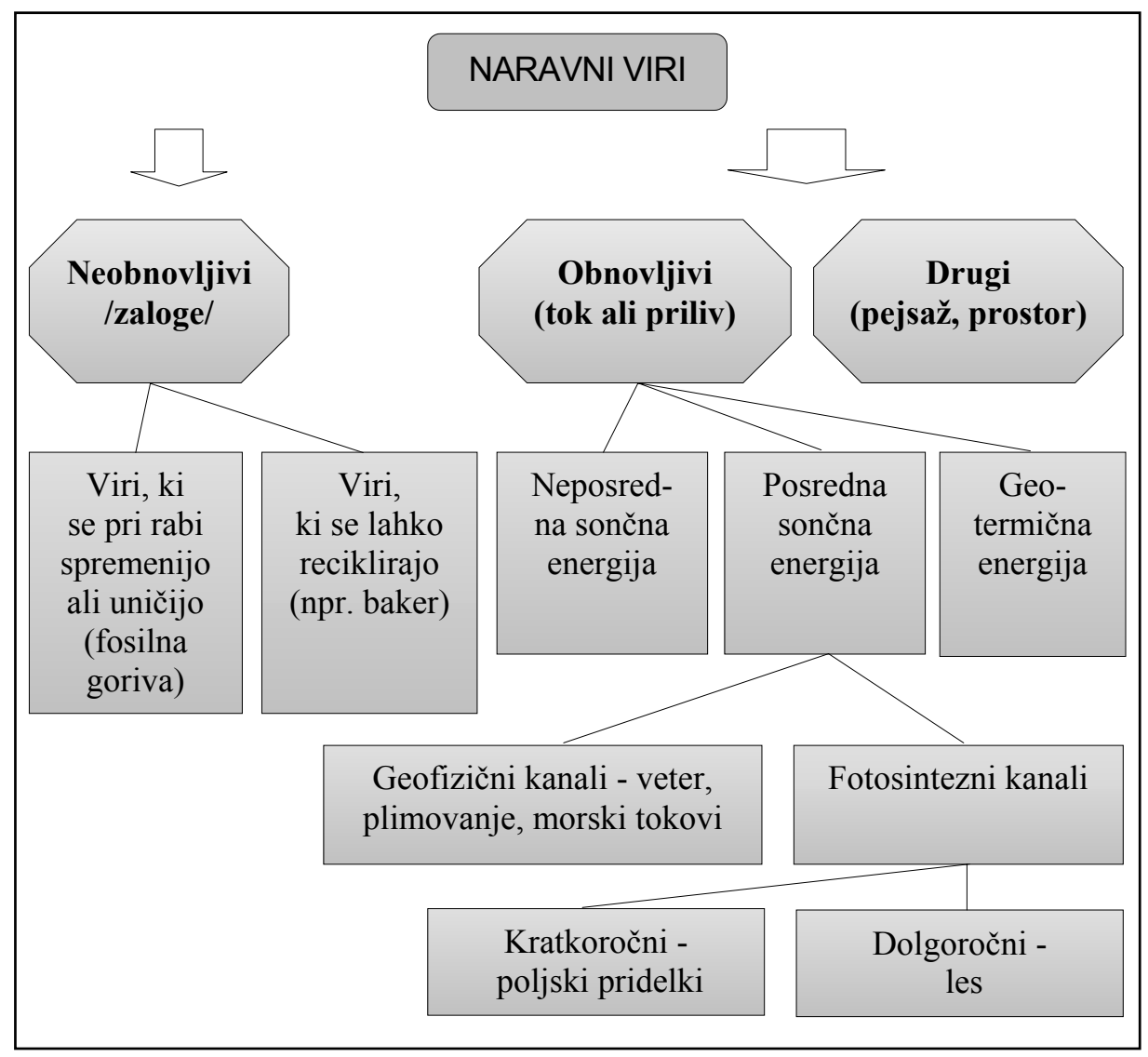




\subsection{Analiza vplivov dejavnosti na naravne potenciale}

Gospodarjenje z okoljem oz. naravnimi viri vključuje upoštevanje naravnih in ekonomskih zakonitosti. Vsaka dejavnost potrebuje določen prostor in od okolja zahteva energijo in prometne možnosti, hkrati pa okolje različno intenzivno obremenjuje ali degradira. Gospodarske in negospodarske dejavnosti so ključni nosilci razvoja in odločilno vplivajo na procese $\mathrm{v}$ prostoru, hkrati pa objektivno predstavljajo največjo nevarnost za okolje. To so industrija, energetika, kmetijstvo, promet, poselitev in turizem. Ni dejavnosti, ki ne bi bila navezana na okolje, številne pa so od naravnih dobrin in vrednot povsem odvisne. Za sleherno dejavnost je potrebno natančno preučiti njen odnos do okolja: kaj iz okolja potrebuje in ali je to sploh uresničljivo, kaj vanj oddaja in ali je to dopustno, kako vpliva na okolje, ali koga ogroža, koga izpostavlja tveganju oz. nevarnostim.

Določena stanja in procese $\mathrm{v}$ prostoru je potrebno tudi kvantitativno ali kvalitativno "izmeriti" oziroma ovrednotiti ter spremljati razvojne trende. To velja tako spremljanje raznovrstnih vplivov na prostor kot, na drugi strani, za odzivanje posameznih sestavin prostora na različne vplive. $Z$ indikatorji za oceno nosilnih (samočistilnih, nevtralizacijskih) sposobnosti okolja in njegovih sestavin se ugotavljajo vplivi dejavnosti na fizično okolje. Prikaže se stopnja ranljivosti okolja kot celote, prav tako pa njegovih pokrajinskih sestavin: zraka, vode (površinske in podtalne), reliefa z litologijo, prsti in vegetacije.

Pri izboru kazalcev za vrednotenje vplivov družbenih elementov prostora in hkrati za vrednotenje odzivov na vplive posameznih dejavnosti so zajete proizvodne in poselitvene strukture, infrastrukturno omrežje in drugi družbeni dejavniki, ki nastopajo v celotnem prostorskem sistemu v dvojni vlogi: kot viri vplivov in kot njihovi prejemniki. Ta sklop med drugim vključuje tudi vplive na kvaliteto življenja $\mathrm{v}$ posamezni regiji na osnovi poznavanja naravnih in antropogenih razmer.

Potrebno je oblikovani tudi kriterije za spremljanje ekonomskih posledic različnih dejavnosti $\mathrm{v}$ prostoru, saj menimo, da je $\mathrm{z}$ vidika strateškega načrtovanja nujno upoštevati tudi stroške, ki nastajajo zaradi nepoznavanja vplivov dejavnosti na okolje.

\section{NARAVNI POTENCIALI KOT BOGASTVO REGIJE}

$\mathrm{V}$ preteklosti so močno poudarjali negativna razmerja in napetosti med okoljem in regionalnim razvojem, danes pa se krepi zavest, da se lahko dopolnjujeta. Okolju je priznana vloga glavnega dejavnika regionalnega razvoja. Nara- 
vni viri (voda, zrak, prsti in drugi) so ključni elementi, ki omogočajo obstoj ljudi in ekosistemov. Kakovost okolja določa tudi privlačnost regije in je kot takšna lokacijski dejavnik pri investicijah (Strateške presoje vplivov regionalnih razvojnih programov na okolje... 2000). Načela okoljskega in trajnostnega razvoja bi morali vključiti v gospodarske sektorje (promet, kmetijstvo, turizem, industrijo, poselitev in energetiko). To pomeni, da moramo načine reševanja okoljskih problemov spremeniti. Namesto da se ukvarjamo s simptomi, bi si morali predvsem prizadevati za vplivanje na oblikovanje in izvajanje politike (Strateške presoje vplivov regionalnih razvojnih programov na okolje ...2000).

Pri planiranju strateških odločitev je nujno upoštevati spoznanja, da določene dejavnosti v Sloveniji, kot so kmetijstvo, promet, energetika, industrija, poselitev in turizem negativno vplivajo na različne segmente okolja. Če torej poznamo pozitivne in negativne vplive posamezne dejavnosti na širše okolje, lahko predvidevamo učinke načrtovanih aktivnosti v regijah, še zlasti zato, da se izognemo nezaželenim posledicam in nepotrebnim stroškom. Pogosto pa se zaradi nepoznavanja vplivov posamezne dejavnosti ali skupine dejavnosti na širše okolje negativne posledice ne odpravijo niti s finančnimi izdatki. Izguba biotske raznovrstnosti, ogroženost zdravega okolja in njegovih sestavin pa bi pomenila izgubo neprecenljivih vrednosti Slovenije in jih je zato treba upoštevati pri vseh razvojnih programih, tako na lokalni, regionalni kot na državni ravni.

Pri analizi naravnih potencialov usmerjamo posebno pozornost kompleksnemu poznavanju regije. Spreminjanje dejavnikov okolja lahko prizadene organizme in izzove strese, njihov vpliv na ljudi je neizbežen, ker pa je vse občutnejši, se prenaša tudi v ekonomsko sfero in se odraža $v$ stroških za saniranje okolja. Degradacija okolja je poslabšanje lastnosti okolja in ravnotežja pojavov, tudi glede dostopnosti, bivalnih, delovnih ali življenjskih pogojev. Pogosto so posledice tega zaznavne na počutju in zdravju ljudi.

\section{TRAJNOSTNA RABA NARAVNIH POTENCIALOV}

Trajnostni kriteriji z vidika naravnih potencialov so opredeljeni v Strategiji 2000:

- čim manjša poraba neobnovljivih virov: $\mathrm{z}$ rabo neobnovljivih virov, kot so fosilna goriva in rude, se zmanjšujejo zaloge, ki jih bodo imeli na voljo prihodnji rodovi. Osnovno načelo trajnostnega razvoja je, da je treba z neobnovljivimi viri ravnati modro in varčno, da se zaradi njihove pretirane porabe ne bi zmanjšale možnosti prihodnjih rodov. To velja za edinstvene in nenadomestljive geološke, ekološke ali pokrajinske elemente in pojave, 
ki so pomembni za produktivnost, biotsko raznovrstnost, znanost in kulturo;

- poraba obnovljivih virov v okviru meja zmožnosti njihovega obnavljanja: pri rabi obnovljivih virov v primarnih dejavnostih, kot so gozdarstvo, ribištvo in kmetijstvo, obstajajo trajnostne meje, če jih presežemo, se začne degradacija naravnih virov. Če uporabljamo ozračje, reke, rečna ustja in morja kot "ponore « za odpadne snovi, jih pravzaprav obravnavamo kot obnovljive vire, saj se zanašamo na njihovo samočistilno sposobnost. Če je ta sposobnost presežena, lahko pride do dolgotrajne degradacije teh naravnih virov. Za cilj si moramo torej zastaviti, da raba naravnih virov ne presega njihove zmožnosti naravnega obnavljanja, saj lahko le tako zagotovimo, da bodo ti viri vsaj $\mathrm{v}$ enaki meri na voljo tudi prihodnjim rodovom;

- ohranjanje in izboljšanje stanja na področju prosto živečega živalstva in rastlinstva, habitatov in pokrajin: temeljno načelo $v$ tem primeru je vzdrževati in izboljšati obseg in kakovost naravne dediščine $\mathrm{v}$ korist sedanjega in prihodnjih rodov. Naravna dediščina vključuje rastlinstvo in živalstvo, geološke in fizičnogeografske pojave ter območja naravne lepote in privlačnosti. Naravna dediščina torej zajema reliefne oblike, habitate, rastlinstvo in živalstvo ter pokrajino, njihove medsebojne povezave in odnose ter njihov rekreacijski potencial. Tesna je tudi medsebojna povezanost naravne in kulturne dediščine;

- vzdrževanje in izboljšanje kakovosti tal in vodnih virov: tla in voda sta obnovljiva naravna vira, ki sta ključnega pomena za zdravje in blaginjo ljudi, ogrožata pa ju predvsem erozija in onesnaževanje. Ključno načelo je torej varovanje obstoječih naravnih virov v količinskem in kakovostnem smislu ter izboljšanje stanja že onesnaženih virov.

Poznavanje ključnih trajnostnih kriterijev je pomembno za izbiranje med razvojnimi alternativami $v$ regiji.

\section{PRIMER ANALIZE NARAVNIH POTENCIALOV IN NJIHOVE RABE V DRAVINJSKIH GORICAH NA OSNOVI BIOTOPOV}

Rezultati študije ranljivosti okolja za Slovenijo so pokazali, da je okolje v Dravinjskih goricah precej degradirano. Čeprav so bile opravljene matrike vplivov za naravne in družbene značilnosti v posameznih mikroregijah Dravinjskih goric, so se pokazale velike razlike znotraj posameznih mikroregij. Zato smo opravili dodatne raziskave $v$ Dravinjskih goricah ter jih razčlenili na biotope. 
Le ti kažejo manjše homogene enote in ugotavljanje vrst in značilnosti naravnih virov je bolj točno, brez posplošitev na večjo teritorialno enoto.

V Dravinjskih goricah so ločimo štiri skupine biotopov, ki se razlikujejo glede na prepustnost prsti in litološke osnove za vodo, osončenost, strmino, nadmorsko višino, mikroklimo, vodno bilanco zraka in prsti, lastnosti prsti, njihovo občutljivost za onesnaževanje, razširjenost gozdov, rabo tal in spreminjanje rodovitnosti prsti.

Biotopi ob reki Dravinji in njenih pritokih so na nadmorski višini 250 $270 \mathrm{~m}$ na holocenskih peščeno ilovnatih in peščeno glinastih naplavinah z recentno akumulacijo, občasnim vplivom podtalne vode in obrečnimi prstmi, prevladujoča raba tal so travniki (označeni so s črko A). Imajo kmetijski, gozdni in poselitveni potencial.

Slika 1: Rastiščni pogoji ob Dravinji so omejeni s plitvimi prstmi

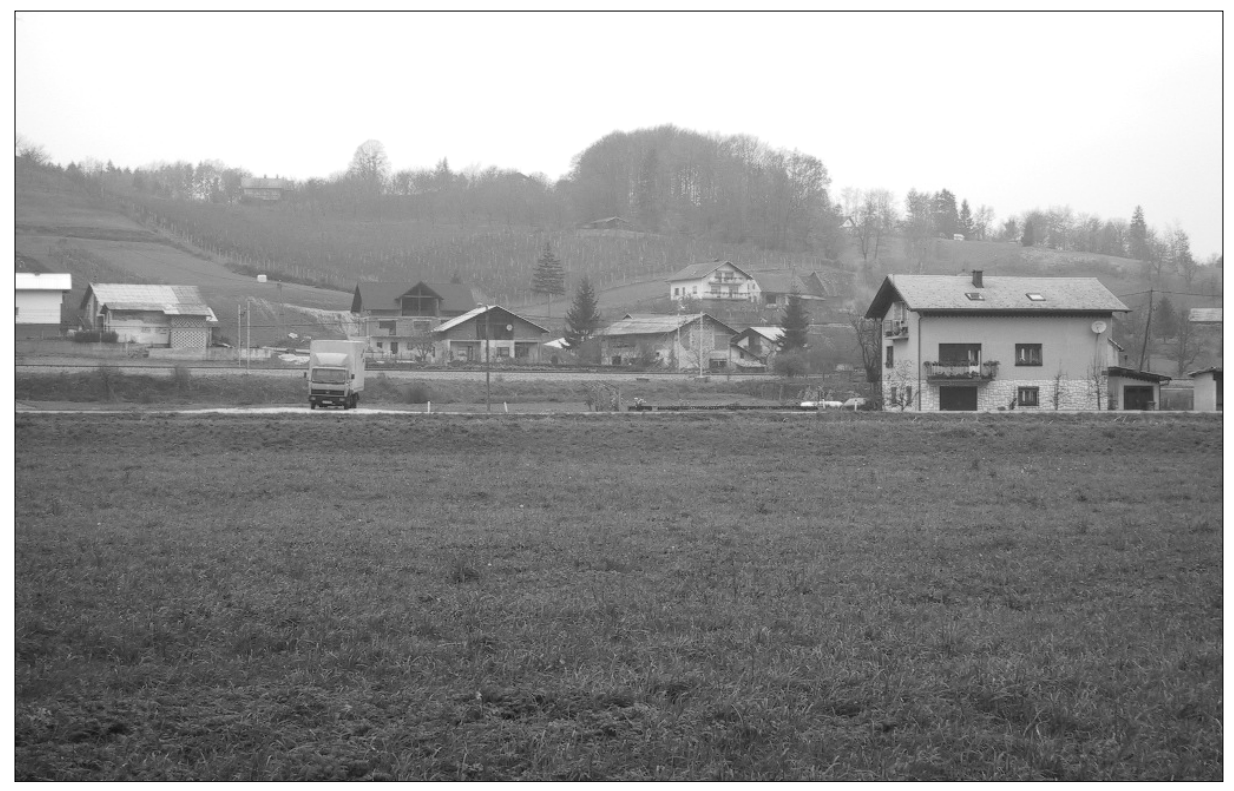

Biotopi v dolini Ložnice so v ravnini, na nadmorski višini $250 \mathrm{~m}$, na pleistocenskih in holocenskih meljasto ilovnatih in meljasto glinasto ilovnatih nanosih, $\mathrm{z}$ rednim zastajanjem vode $\mathrm{v}$ hidromorfnih prsteh in oglejevanjem. V dolini Ložnice imajo biotopi kmetijski in gozdni potencial. Meja med njima je jasno ločena. Označeni so s črko B. 
Slika 2: Obsežne njivske površine v dolini Ložnice z zastajajočo vodo

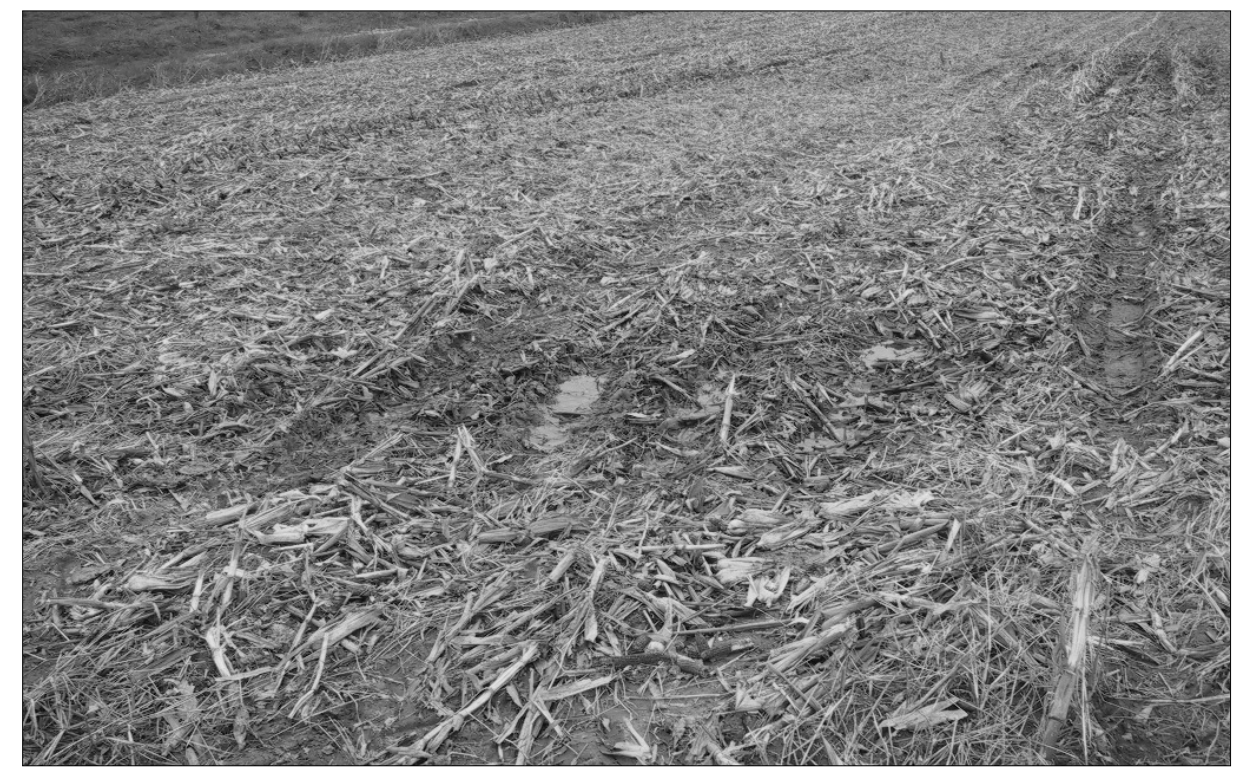

Slika 3: Vinogradi so omejeni na redke lege vodo

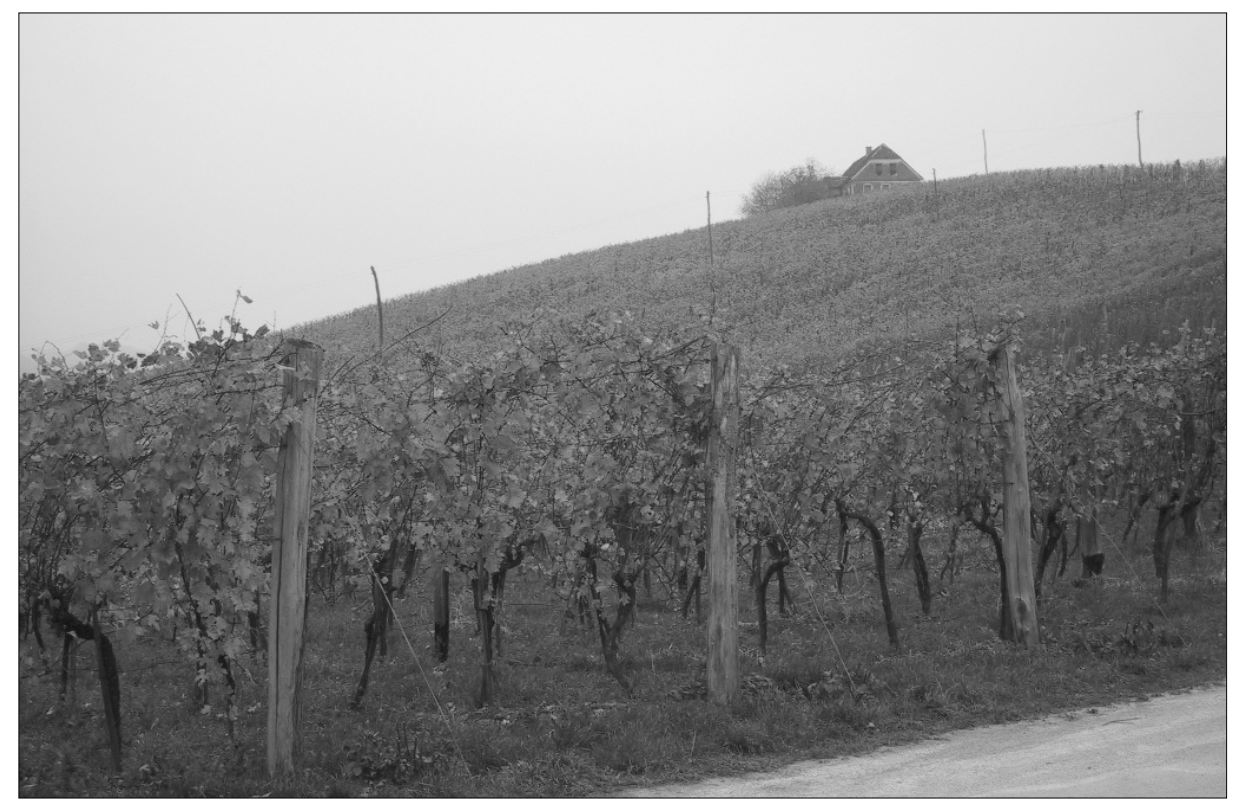


Biotopi v južnem delu Dravinjskih goric ležijo na reliefno razčlenjenem gričevju iz laporja, na nadmorski višini 300 do $450 \mathrm{~m}$, zaradi slabe prepustnosti laporjev za podzemni odtok vode se uveljavlja močna denudacija. Distrične in evtrične prsti so namenjene mešani njivsko - travniški in gozdni rabi. Ti biotopi imajo kmetijski in gozdni potencial, označeni so s črko C.

Slika 4: Gozdnate osrednje Dravinjske gorice

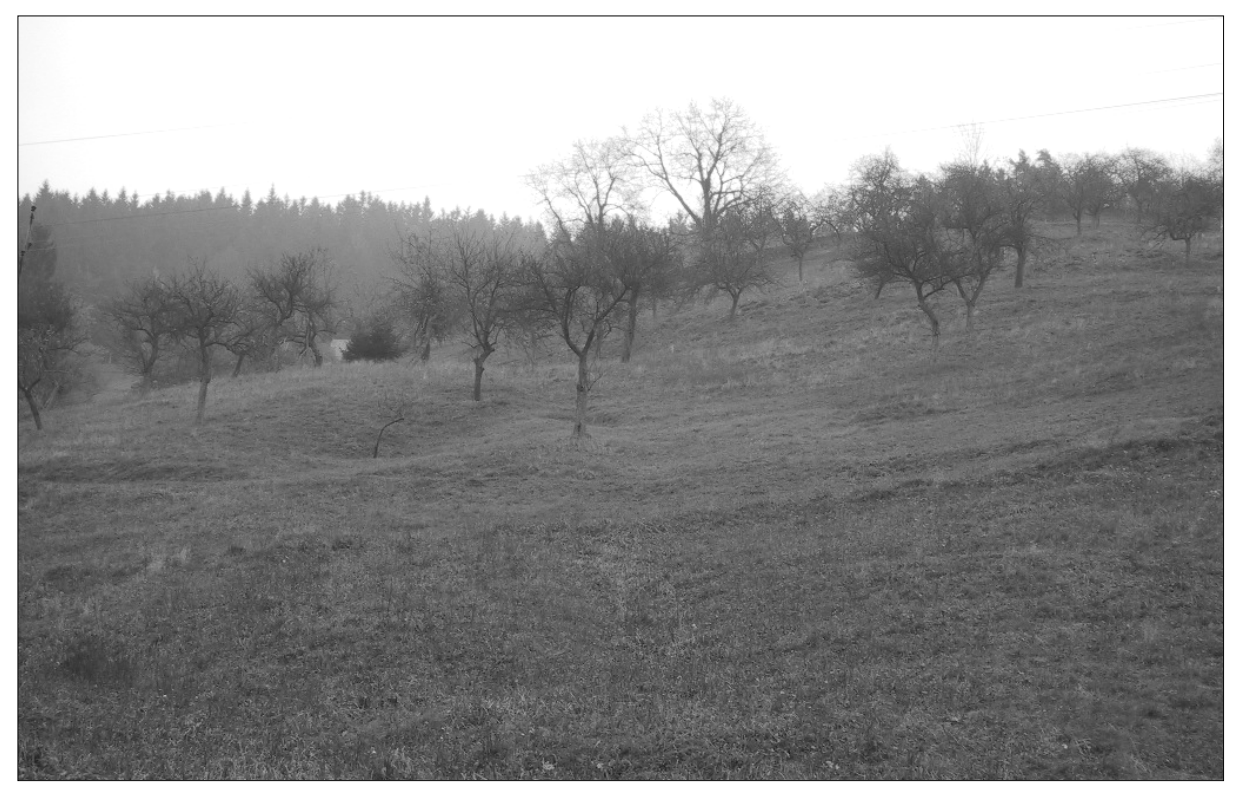

Osrednje Dravinjske gorice so blago razrezano gričevje iz pleistocenskih ilovic s prodom in peskom, močno denudacijo na slemenih in koluviacijo ob vznožjih pobočij, zaradi neodpornosti litološke osnove in humidne klime ter s procesi psevdoogljevanja zaradi občasnega zastajanja padavinske vode $\mathrm{v}$ profilu prsti. Najpomembnejši potencial teh biotopov je gozd. Biotopi so označeni $\mathrm{s}$ crko D. 
Tabela 1: Geografske značilnosti biotopov v Dravinjskih goricah

\begin{tabular}{|c|c|c|c|c|}
\hline Biotopi & $\begin{array}{l}\text { Biotopi v dolini } \\
\text { Dravinje in ob } \\
\text { njenih pritokih }\end{array}$ & $\begin{array}{l}\text { Biotopi } \\
\text { v dolini } \\
\text { Ložnice }\end{array}$ & $\begin{array}{c}\text { Biotopi v } \\
\text { južnem delu } \\
\text { Dravinjskih } \\
\text { goric }\end{array}$ & $\begin{array}{c}\text { Biotopi } \\
\text { osrednj. dela } \\
\text { Dravinjskih } \\
\text { goric }\end{array}$ \\
\hline $\begin{array}{l}\text { LITOLOŠKA } \\
\text { OSNOVA }\end{array}$ & $\begin{array}{l}\text { peščeno } \\
\text { ilovnate in } \\
\text { glinaste } \\
\text { naplavine }\end{array}$ & $\begin{array}{l}\text { meljasto- } \\
\text { glinaste } \\
\text { naplavine }\end{array}$ & lapor & $\begin{array}{l}\text { ilovica } \\
\text { in pesek }\end{array}$ \\
\hline $\begin{array}{l}\text { RELIEF } \\
\text { Nadmor. v. m } \\
\text { naklon }^{\circ} \\
\text { ekspozicija }\end{array}$ & $\begin{array}{l}250-270 \\
0-2 \\
-\end{array}$ & $\begin{array}{l}250 \\
0-2 \\
-\end{array}$ & $\begin{array}{l}300-450 \\
10-20 \\
\text { j, s }\end{array}$ & $\begin{array}{l}280-350 \\
5-20 \\
\text { (vse) }\end{array}$ \\
\hline $\begin{array}{l}\text { KLIMATSKI } \\
\text { PODATKI } \\
\mathrm{T}^{\circ} \mathrm{C} \text { - leto } \\
\mathrm{T}^{\circ} \mathrm{C} \text { - veg.doba } \\
\mathrm{T}^{\circ} \mathrm{C} \text { - poletje } \\
\mathrm{T}^{\circ} \mathrm{C} \text { - zima } \\
\mathrm{P}^{\mathrm{m} m} \text { - leto }\end{array}$ & $\begin{array}{l}9.5 \\
15.5 \\
18.1 \\
0.4 \\
1076 \\
\end{array}$ & $\begin{array}{l}9.4 \\
15.6 \\
18.4 \\
-0.2 \\
1012 \\
\end{array}$ & $\begin{array}{l}9.5 \\
15.5 \\
18.1 \\
0.4 \\
1076 \\
\end{array}$ & $\begin{array}{l}9.5 \\
15.5 \\
18.1 \\
0.4 \\
1074 \\
\end{array}$ \\
\hline $\begin{array}{l}\text { VODNA } \\
\text { BILANCA } \\
\text { PE mm - leto } \\
\text { VS mm - leto } \\
\text { VD mm - leto } \\
\text { Im }\end{array}$ & $\begin{array}{l}642.1 \\
406.4 \\
0 \\
63.3\end{array}$ & $\begin{array}{l}622.4 \\
339.2 \\
0 \\
62.6\end{array}$ & $\begin{array}{l}642.1 \\
406.4 \\
0 \\
63.3\end{array}$ & $\begin{array}{l}642.1 \\
406.4 \\
0 \\
63.3\end{array}$ \\
\hline $\begin{array}{l}\text { PRSTI } \\
\text { prevladujoča prst } \\
\text { tekstura } \\
\% \text { vode } \\
\text { PVK mm } \\
\text { Kf cm } / \mathrm{sec}^{*} 10^{-3}\end{array}$ & $\begin{array}{l}\text { obrečna A-C } \\
\text { PI, I } \\
20-25 \\
162 \\
3.1\end{array}$ & $\begin{array}{l}\text { Hidromelio- } \\
\text { rirana MI } \\
22 \\
124 \\
2.3\end{array}$ & $\begin{array}{l}\text { evtrična in } \\
\text { distrična IG } \\
18 \\
142 \\
4\end{array}$ & $\begin{array}{l}\text { evtrična pse- } \\
\text { vdooglej. IG } \\
22 \\
140 \\
1.3\end{array}$ \\
\hline $\begin{array}{l}\text { GOZDNE } \\
\text { ZDRUŽBE }\end{array}$ & - & $\begin{array}{l}\text { gozd doba in } \\
\text { evropske } \\
\text { gomoljčice }\end{array}$ & $\begin{array}{l}\text { gozd belega } \\
\text { gabra s } \\
\text { čremso }\end{array}$ & $\begin{array}{l}\text { gozd bukve s } \\
\text { kostanjem }\end{array}$ \\
\hline $\begin{array}{l}\text { RABA } \\
\text { TAL }\end{array}$ & travniki & $\begin{array}{l}\text { Hidmeliori- } \\
\text { rane njive in } \\
\text { gozd }\end{array}$ & $\begin{array}{l}\text { njive, travni- } \\
\text { ki,vinograd, } \\
\text { gozd }\end{array}$ & $\begin{array}{l}\text { gozd, njive in } \\
\text { travniki }\end{array}$ \\
\hline $\begin{array}{l}\text { ANTROPOGENI } \\
\text { POSEGI }\end{array}$ & - & $\begin{array}{l}\text { agrohidrome- } \\
\text { lioracije }\end{array}$ & rigolanje & - \\
\hline
\end{tabular}

Analiza Dravinjskih goric iz vidika naravnih značilnosti je pokazala, da so za to regijo značilni gozdni, kmetijski in poselitveni potencial. 


\section{Tabela 2: Biotopi in njihova raba}

\begin{tabular}{|c|c|c|}
\hline $\begin{array}{c}\text { oznaka } \\
\text { biotopov }\end{array}$ & Lastnosti biotopov & dejavnost \\
\hline A11 & $\begin{array}{l}\text { travniki, občasno poplavljeni, na plitvi obrečni } \\
\text { prsti }\end{array}$ & ekstenzivno kmetijstvo \\
\hline A12 & obdelana polja na plitvi obrečni prsti & intenzivno kmetijstvo \\
\hline A21 & obdelana polja in travniki na hipogleju & ekstenzivno kmetijstvo \\
\hline A22 & travniki na hipogleju & ekstenzivno kmetijstvo \\
\hline A23 & pozidano & poselitev \\
\hline A31 & $\begin{array}{l}\text { obdelana polja in travniki na ravninskem psevdo- } \\
\text { gleju }\end{array}$ & ekstenzivno kmetijstvo \\
\hline A32 & $\begin{array}{l}\text { gozdovi belega gabra z belkasto bekico na ravnin- } \\
\text { skem psevdogleju }\end{array}$ & gozdarstvo \\
\hline A33 & pozidano & poselitev \\
\hline A34 & nerodovitno & infrastruktura \\
\hline B11 & hidromeliorirane njive na amfigleju & Intenzivno kmetijstvo \\
\hline B12 & travniki na amfigleju & Ekstenzivno kmetijstvo \\
\hline $\mathrm{B} 13$ & gozd črne jelše in podaljšanega šaša na amfigleju & gozdarstvo \\
\hline $\mathrm{B} 14$ & dobov gozd na amfigleju & gozdarstvo \\
\hline $\mathrm{B} 21$ & travniki na ravninskem psevdogleju & Ekstenzivno kmetijstvo \\
\hline $\mathrm{B} 22$ & $\begin{array}{l}\text { gozd belega gabra s čremso na ravninskem psev- } \\
\text { dogleju }\end{array}$ & Gozdarstvo \\
\hline $\mathrm{C} 11$ & vinogradi na rigolanih prsteh & intenzivno kmetijstvo \\
\hline $\mathrm{C} 21$ & njive in travniki na distrični prsti & ekstenzivno kmetijstvo \\
\hline $\mathrm{C} 22$ & $\begin{array}{l}\text { gozd belega gabra z belkasto bekico na distrični } \\
\text { rjavi prsti }\end{array}$ & gozdarstvo \\
\hline $\mathrm{C} 23$ & bukov gozd na distrični rjavi prsti & gozdarstvo \\
\hline $\mathrm{C} 31$ & njivsko travniška raba na evtrični rjavi prsti & ekstenzivno kmetijstvo \\
\hline $\mathrm{C} 32$ & bukov gozd na evtrični rjavi prsti & gozdarstvo \\
\hline $\mathrm{C} 33$ & $\begin{array}{l}\text { gozd belega gabra in belkaste bekice na evtrični } \\
\text { rjavi prsti }\end{array}$ & gozdarstvo \\
\hline $\mathrm{C} 34$ & bukov gozd s kostanjem na evtrični rjavi prsti & gozdarstvo \\
\hline $\mathrm{C} 35$ & hrastovi in gabrovi gozdovi na evtrični rjavi prsti & gozdarstvo \\
\hline D11 & $\begin{array}{l}\text { njivsko-travniška raba na pobočju na evtrični rjavi } \\
\text { prsti }\end{array}$ & ekstenzivno kmetijstvo \\
\hline D12 & $\begin{array}{l}\text { acidofilni bukovi gozdovi s kostanjem na pobočjih } \\
\text { na rankerju }\end{array}$ & gozdarstvo \\
\hline D21 & $\begin{array}{l}\text { njivsko travniška raba z razpršeno poselitvijo na } \\
\text { evtričnih rjavih na psevdogleju }\end{array}$ & Ekstenzivno kmetijstvo \\
\hline D22 & $\begin{array}{l}\text { acidofilni bukovi in kostanjevi gozdovi na evtrič- } \\
\text { nih rjavih prsteh }\end{array}$ & gozdarstvo \\
\hline $\mathrm{D} 31$ & njivsko travniška raba na pobočnem psevdogleju & Ekstenzivno kmetijstvo \\
\hline D32 & $\begin{array}{l}\text { acidofilni bukov gozd s kostanjem na pobočnem } \\
\text { psevdogleju }\end{array}$ & gozdarstvo \\
\hline D33 & pozidano & poselitev \\
\hline
\end{tabular}


Grafikon 1: Raba tal na območju Dravinjskih goric

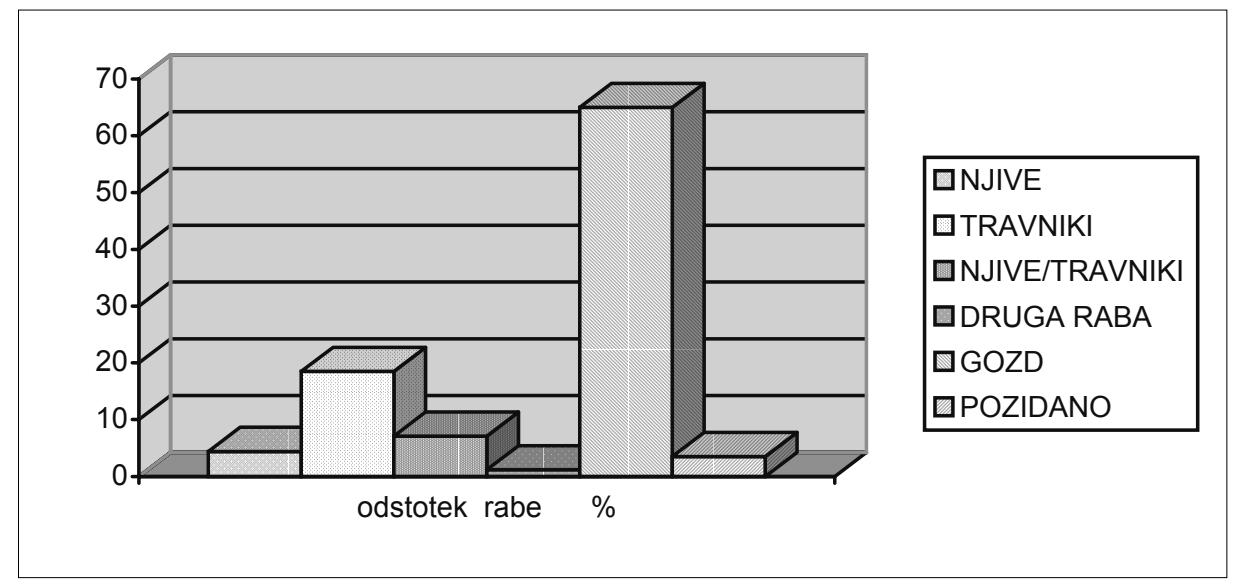

Biotopi izkazujejo značilno združbo rastlin ali obliko rabe tal skupaj z neživimi dejavniki okolja (kot so svetloba, vlaga, tip prsti) in so v prostoru jasno ločeni med seboj. So podobni habitatnim tipom (tipom življenjskega prostora) in predstavljajo zbirko podatkov, izraženih ploskovno. Poznavanje biotopov omogoča načrtovanje skladne rabe prostora. Opažamo, da so bile dejavnosti v preteklosti veliko bolj odvisne od naravnih virov pokrajine in so jih tudi pri rabi upoštevali, zato se je gozd po opustitvi kmetovanja hitro zarasel.

Analiza gozdov kot najpomembnejšega potenciala v Dravinjskih goricah je pokazala precejšnjo osutost dreves, kljub dejstvu, da danes v Dravinjskih goricah ni večjih industrijskih centrov.

\section{ZAKLJUČEK}

Teoretične opredelitve naravnih virov in potencialov so veliko širše kot se ti pojmi uporabljajo v praksi. V študijah ranljivosti okolja se od naravnih virov omenjajo le vode, mineralne surovine, prsti in gozd. Strokovna znanja o naravnih virih in njihovi rabi (potencialih) bi bilo potrebno uporabljati enotno. V pregledanih študijah o ranljivosti okolja za posamezne mestne občine so naravni viri preozko razumljeni.

Pri načrtovanju rabe naravnih virov se uporabljajo različni pristopi. Pri t.i. pokrajinsko ekološkem pristopu se območje razčleni na pokrajinsko ekološke enote in te so osnova za vrednotenje naravnih virov in njihove rabe. Glavni očitek temu pristopu je, da so vsi podatki, tudi točkovni prikazani na ploskovni ravni. Pri drugem pristopu, ki izhaja le iz dejavnosti in vrednoti 
narave vire in njihovo rabo preko različnih dejavnosti, se ločeno obravnava vpliv posamezne dejavnosti na posamezno sestavino narave, na naravne vire ter na bivalno okolje. Zaradi premalo povezovalnega pristopa se zdi, da je pokrajina sestavljena iz ločenih sestavin, dejansko pa se le te prepletajo.

Na primeru Dravinjskih goric smo uporabili metodo evidentiranje naravnih virov in njihove rabe na osnovi biotopov. Ker so le ti majhne homogene enote, lahko na osnovi biotopov dobimo natančen pregled na sestavinami in njihovo rabo. Prednost tovrstnega pristopa je $\mathrm{v}$ tem, da dobimo kvantitativne in opisne podatke o notranji sestavi pokrajine ter zunanjem izgledu.

Iz stališča trajnostne rabe naravnih potencialov bi na osnovi poznavanja notranje zgradbe in lastnosti pokrajine upoštevali dejavnosti in njihov vpliv na naravno in družbeno okolje.

\section{Viri in literatura:}

A European System of Environmental Pressure Indices. First Volume of the Environmental Pressure Indices Handbook: The Indicators. http://esl.jrc.it/ envind/theory/handb .htm

Diercke Woerterbuch Allgemeine Geographie. 1997, str. 451.

Enciklopedija Slovenije, 1993. Geslo Naravni viri, št. 7., Mladinska knjiga.

European Environment Information and Observation Network (EIONET). http://www.eionet.eu.int/

Geografija, enciklopedija. 1993, Mladinska knjiga.

Ilešič, S., 1974: Pogledi na geografijo. Ljubljana

Lokalna agenda 21 (Osnutek). Mestna občina Maribor, november 2000.

Plut, D., 1998. Varstvo geografskega okolja. Univerza v Ljubljani, Filozofska fakulteta, Oddelek za geografijo, Ljubljana.

Radej, B., Pirc Velkavrh, A., Globevnik, L., 1999: Indikatorji o okolju in razvoju / Indicators on environment and development. Ljubljana.

Strateške presoje vplivov regionalnih razvojnih programov na okolje in programi Strukturnih skladov Evropske unije. Regionalni center za okolje za srednjo in vzhodno Evropo. Evropska komisija, Generalni direktorat za okolje. Prevajalec Roman Šimec. Regionalni center za okolje za srednjo in vzhodno Evropo, Ljubljana 2000.

Špes, M. et al., 1996: Študija ranljivosti okolja. Vsebina in metodologija kot osnova za pripravo podzakonskega akta. Ljubljana.

Špes, M. , Cigale, D., Lampič, B., Natek, K., Plut, D., Smrekar, A., Vovk Korže, A, 1999: Ranljivost okolja kot omejitveni dejavnik prostorskega razvoja Slovenije : zaključno poročilo. Ljubljana: Inštitut za geografijo. 
Študija ranljivosti okolja za prostorski plan MO Nova Gorica, 2000. Urbanistični inštitut RS.

Vovk Korže, A., 1997: Regional ecological units of northeastern Slovenia. Geografski zbornik. [English ed., 1996, let. 36, 48 str. Dostopno na internetu: http://www.zrc-sazu. si/www/gi/zbornik-a.htm , 29.januar 1997.

Vovk Korže, A., Korže, D., 2001: Landscape units in Northeastern Slovenia. Journal of Balkan ecology, vol. 4, no. 2.

\section{NATURRAUMPOTENTIALE UND IHRE NUTZUNG}

\section{Zusammenfassung}

Naturraumpotential bedeutet die Teile des Naturraumdargebots, die für bestimmte Nutzungen durch den Menschen von Interesse sind und dafür ein feststellbares Leistungsvermögen aufweisen. Aber Naturressourcen sind jener Teil der Naturraumpotentiale, der in ökonomische Beziehungen eintritt oder dafür vorgesen ist. Naturresourcen sind somit ein ökonomischer Begriff, da eine Wertung der Nutzungsmöglichkeit vorgenommen wird, auch wenn die Bezugsbasis die Naturraumausstattung bzw. das Naturraumdargebot ist.

Naturraumpotentiale und ihre Nutzung sind Bestandteil der Raumplan der Republik Slovenien. Sehr oft haben die Tätigkeiten bedeutende Rolle bei der Empfindlichkeit der Natur, ohne die Beachtung der Umwelt als Ganzsystem. Mit der Nutzung der Naturraumpotentialen verändert sich:

- physikalische Umgebung (Naturraum mit Bestandteilen)

- Menschumgebung (Qualität der Leben, Aussicht der Landschaft, Abfallwirtschaft, Lärm) und - ökonomische Aspekt der Umwelt, es geht für die Kosten, die wegen negative Einflüsen der Tätigkeiten eingestanden sind.

Bei der Plannirung der Tätigkeiten in der Raum, nach der Stategie 2000 muss man folgendne Schritte beachten:

- feststellen der Eigenschaften der Naturraumpotential

- Beschreibung der Naturraumpotential

- Ausforschen der Drück der Menschen an der Natur.

Das Ziel der Bewertung der Naturraumpotential ist die Nachhaltigkeit der Entwicklung. Einigene Tätigkeiten haben negative Einflüsse an die Umwelt. Für die Entwicklungsalternative in der Region muss man die Nachhaltigkeit beachten.

Folgende Beispiel der Naturraumpotentialen und ihre Nutzung in Dravinja Hügelland zeigt die Ausgangpunkte fur solche Umweltanalyse. 
Geographische Eigenschaften der Biotope in Dravinja Hügelland

\begin{tabular}{|c|c|c|c|c|}
\hline Biotope & Dravinja Tal & Ložnica Tal & $\begin{array}{c}\text { Südteil des } \\
\text { Dravinja } \\
\text { Hügellands }\end{array}$ & Mittelteil \\
\hline Testgebiete & $\begin{array}{l}\text { Dravinja } \\
\text { Hügelland }\end{array}$ & $\begin{array}{l}\text { Dravinja } \\
\text { Hügelland }\end{array}$ & $\begin{array}{l}\text { Dravinja } \\
\text { Hügelland }\end{array}$ & $\begin{array}{l}\text { Dravinja } \\
\text { Hügelland }\end{array}$ \\
\hline LITHOLOGIE & $\begin{array}{l}\text { sandlehmige } \\
\text { und tonige } \\
\text { Ablagerungen }\end{array}$ & $\begin{array}{l}\text { schlufftonige } \\
\text { Ablagerungen }\end{array}$ & Mergel & $\begin{array}{l}\text { Lehm und } \\
\text { Sand }\end{array}$ \\
\hline $\begin{array}{l}\text { RELIEF } \\
\text { Seehohe, m } \\
\text { Neigung }{ }^{\circ} \\
\text { Exposition }\end{array}$ & $\begin{array}{l}250-270 \\
0-2 \\
-\end{array}$ & $\begin{array}{l}250 \\
0-2 \\
-\end{array}$ & $\begin{array}{l}300-450 \\
10-20 \\
N, S\end{array}$ & $\begin{array}{l}280-350 \\
5-20 \\
\text { alle }\end{array}$ \\
\hline $\begin{array}{l}\text { KLIMATISCHE } \\
\text { ANGABEN } \\
\mathrm{T}^{\circ} \mathrm{C} \text { - Jahr } \\
\mathrm{T}^{\mathrm{o}} \mathrm{C} \text { - veget. } \\
\text { Periode } \\
\mathrm{T}^{\mathrm{o}} \mathrm{C} \text { - Sommer } \\
\mathrm{T}^{\mathrm{o}} \mathrm{C} \text { - Winter } \\
\mathrm{P} \text { mm - Jahr }\end{array}$ & $\begin{array}{l}9.5 \\
15.5 \\
\\
18.1 \\
0.4 \\
1076\end{array}$ & $\begin{array}{l}9.4 \\
15.6 \\
\\
18.4 \\
-0.2 \\
1012\end{array}$ & $\begin{array}{l}9.5 \\
15.5 \\
\\
18.1 \\
0.4 \\
1076\end{array}$ & $\begin{array}{l}9.5 \\
15.5 \\
\\
18.1 \\
0.4 \\
1074\end{array}$ \\
\hline $\begin{array}{l}\text { WASSER } \\
\text { BILANZ } \\
\text { PE mm - Jahr } \\
\text { VS mm - Jahr } \\
\text { VD mm - Jahr } \\
\text { Im }\end{array}$ & $\begin{array}{l}642.1 \\
406.4 \\
0 \\
63.3 \\
\end{array}$ & $\begin{array}{l}622.4 \\
339.2 \\
0 \\
62.6 \\
\end{array}$ & $\begin{array}{l}642.1 \\
406.4 \\
0 \\
63.3 \\
\end{array}$ & $\begin{array}{l}642.1 \\
406.4 \\
0 \\
63.3 \\
\end{array}$ \\
\hline $\begin{array}{l}\text { BODEN } \\
\text { Bodentyp } \\
\text { Textur } \\
\% \text { Wasser } \\
\mathrm{nF} \mathrm{mm} \\
\mathrm{Kf} \mathrm{cm} / \mathrm{sec}^{*} 10^{-3}\end{array}$ & $\begin{array}{l}\text { Auenboden } \\
\text { A-C } \\
\text { PI, I } \\
20-25 \\
162 \\
3.1 \\
\end{array}$ & $\begin{array}{l}\text { hidromeliora- } \\
\text { tionen } \\
\mathrm{zL} \\
22 \\
124 \\
2.3\end{array}$ & $\begin{array}{l}\text { Braunerde } \\
\text { lT } \\
18 \\
142 \\
4\end{array}$ & $\begin{array}{l}\text { Pseudogley, } \\
\text { Braunerde } \\
\text { 1T } \\
22 \\
140 \\
1.3 \\
\end{array}$ \\
\hline $\begin{array}{l}\text { WALD } \\
\text { GEMEIN- } \\
\text { SCHAFTE }\end{array}$ & - & $\begin{array}{l}\text { Pseudo- } \\
\text { stellario } \\
\text { Carpinetum }\end{array}$ & $\begin{array}{l}\text { Pruno padi - } \\
\text { Carpinetum }\end{array}$ & $\begin{array}{l}\text { Castaneo- } \\
\text { Fagetum }\end{array}$ \\
\hline $\begin{array}{l}\text { BODEN } \\
\text { NUTZUNG }\end{array}$ & Wiese & $\begin{array}{l}\text { Acker, } \\
\text { Wald }\end{array}$ & $\begin{array}{l}\text { Acker, Wiese, } \\
\text { Wald, } \\
\text { Weinbau }\end{array}$ & $\begin{array}{l}\text { Wald } \\
\text { Acker } \\
\text { Wiese }\end{array}$ \\
\hline $\begin{array}{l}\text { ANTHRO- } \\
\text { POGENE } \\
\text { EINGRIEFE }\end{array}$ & - & $\begin{array}{l}\text { agrohidro- } \\
\text { meliorationen }\end{array}$ & $\begin{array}{l}\text { rigosol- } \\
\text { Bearbeitung }\end{array}$ & - \\
\hline
\end{tabular}


Biotopen in den Talauen, 250-270 M über dem Mehhresspiegel, aus der Sandtonigen und Sandtonigen Ablagerungen mit Rezenten Akumulation und Anschwemmungen. Horizont - Differenzierung ist schlecht erkennbar. Auenboden, Gley und Pseudogley. Vorwiegende Nutzung sind Weise.

Biotopen der Ebene, Seehöhe $250 \mathrm{M}$, aus den Pliozäne und Holozäne Schluff-Lehmigen und Schluff-tonigen Ablagerungen, hoheres Grundwasserspiegel mit Oxidations Go und reduktions Gr Horizont und Bodentyp Gley.

Biotopen in den Hügelland aus dem Mergel, 300 - $450 \mathrm{M}$, wegen der schlechten Wasserdurchlässigkeit kommt es zur starken Denudation. Braunerde, gemischte Acker-Wiese und Wald Nutzung.

Biotopen in den Hügelland aus dem Pleistozänen Lehm mit dem Kies und Sand, mit starken Denudation und Kolluvialen prozessen. In Bv Horizont gereinge Pseudogleyung (Bv/S oder BvS) Profil.

Die Kenntnis über der komplexen Realität der Landschaft ist eine wichtige Voraussetzung für die Nutzungsplanung. Ausgewalte Beispiele der Standortuntersuchungen zeigen die Bedeutung einer komplexen Standortanalyse und Syntese für die Landschaftsnutzung. 